
visualization in photography:

\author{
Soviet and Russian multisemiotics
}

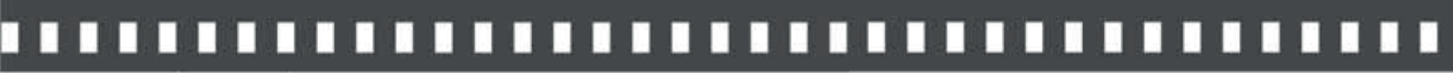

\author{
Oleg Pavenkov \\ Maria Rubtsova \\ Ilya Shmelev
}

Article received in: 11/12/2016

Article approved in: 18/06/2018

D0I 10.5433/1984-7939.2018v14n24p229 


\title{
The transformation of gender visualization in photography: Soviet and Russian multisemiotics
}

\section{A transformação da visualização de gênero em fotografia: multisemiótica russa e soviética}

\author{
0leg Pavenkov" \\ Maria Rubtsova** \\ Ilya Shmelev ${ }^{* * *}$
}

\begin{abstract}
The article is devoted to the analysis of the construction of new system of gender images in the sociopolitical conditions in Russia during the last thirty ages. Based on Kress and Van Leeuwen multisemiotic theory and the ideas A. Dudareva, I.Groshev and M. Petrova, we conducted a research of gender images of women in the Soviet Union and modern Russian advertising. The data comes from 300 images of the Russian men and women in advertising. These 300 images were specifically chosen by the author in order to be acceptable for coding. As the result of the study, we developed the typology of gender images of woman in Russian advertisement. Our conclusion was that economic, political and socio-cultural factors were the main factors in the transformation of gender images in modern Russia. The gender of a woman, her body and figures as shown in the media, very often were object of sexual exploitation, when the impact of using the image and play with human sexual passion forces her to commit certain actions, such as buying goods. This characteristic of our commercialization of gender images turns a person, both men
\end{abstract}

\footnotetext{
* Doctoral degree in Theology (Estern Pontifical Institute (Rome). Lecturer in the Department of Advertising and Public Relations at the St. Petersburg Institute of Cinema and Television - Russia. E-mail: infosoc@bk.ru

${ }^{* *}$ Associate Professor in the Department of Social Management and Planning at the Saint Petersburg State University, Russia.

${ }^{* * *}$ Senior Lecturer and $\mathrm{PhD}$ student at National Research University Higher School of Economics. Research University Higher School of Economics, Faculty of Social Sciences, Department of Psychology, Moscow, Russian Federation.
} 
and women, into a commodity. Gender is becoming the object that can be purchased and can be enjoyed.

Keywords: Gender image. Socio-political conditions in Russia. Images.

Resumo: $O$ artigo é dedicado à análise da construção de um novo sistema de imagens de gênero nas condições sóciopolíticas na Rússia durante os últimas trinta anos. Com base na teoria multissemiótica e nas ideias de Kress e Van Louis, A Dudareva, I. Groshev e M. Petrova, realizamos uma pesquisa de imagens de gênero de mulheres na União Soviética e na moderna publicidade russa. Os dados são provenientes de 300 imagens de homens e mulheres russos em peças de publicidade. Essas 300 imagens foram particularmente escolhidas pelo autor, a fim de permitir adequada codificação. Como resultado do estudo, desenvolvemos a tipologia de imagens de gênero da mulher na propaganda russa. Nossa conclusão foi de que fatores economicos, politicos e socioculturais foram os principais elementos na transformação de imagens de gênero na Rússia moderna. O gênero de uma mulher, seu corpo e figuras como mostrado na mídia, muitas vezes eram objeto de exploração sexual, quando o impacto de usar a imagem e brincar com a paixão sexual humana acaba por forçála a cometer certas ações, como a compra de bens. Esta característica de nossa comercialização de imagens de gênero transforma uma pessoa, tanto homens como mulheres, em uma mercadoria. Gênero está se tornando o objeto que pode ser comprado e pode ser desfrutado.

Palavras-chave: Imagens de gênero. Condições sociopolíticas na Rússia. Imagens.

\section{Introduction}

Changes in the socio-political conditions in Russia during last thirty ages influence the construction of gender images and values that can be expressed in gender self-presentations. Social discourses are devoted to the transformation of gender images in 
Russia. We consider the processes of transformation of gender images and values since the middle of 1980. The psychological aspects of system of gender values in connection with coping behavior were considered in articles of Petrovskii V. (2001), Ilya Shmelev (2015), Pavenkov and Rubtcova (2016a, 2016b).

Gender images are quite complex objects of analysis. It seems we can see and understand the meanings of photos effortlessly. "Images are often used to bring a sense of immediacy and reality to the text in a way that promotes interaction with the reader" (MARTÍNEZ LIROLA, 2006, p. 253). However, it is difficult to describe the meanings of photos in terms of analytical and research tools. That is why the social and language meanings of photos were situated outside the centre of social researchers' attention. Roland Barthes confirms this idea, reasoning about the analysis of "the air of a face": "The air of a face is unanalyzable (once I can decompose, I prove or I reject, in short I doubt, I deviate from the Photograph, which is by nature totally evidence: evidence is what does not want to be decomposed)" (BARTHES, 1981, p. 107-109).

Roland Barthes's contribution has served as a very useful idea for the further discussions of a photograph as a multimodal social phenomenon. Speaking about "the ways in which the meanings of images have been framed and adjudicated" John Tagg notes that these ways are connected with "the institutionalized function of the photograph as a privileged form of evidence which has been so important to certain processes of power" (TAGG, 2009, p. Xv-Xvi). From this point of view, the social aspects of images cannot be examined in isolation from their ideological function. To some extent, it is a focus on ideology of the power in photos 
(BRECKNER, 2008; SCHILL, 2012).

In Russia, there have been several studies based on these ideas. Russian researchers have been looking at photos of Soviet leaders as the visible presence of Soviet ideology see e.g. (OREH, 2012; VENTSEL, 2010). To sum up, it is generally thought that Soviet and Russian photos have been considered as a power and social phenomenon. However, this type of research had a big drawback of subjectivity in interpretation. As a result, until the end of the 1990s, the majority of social researchers considered photos as unworthy of scientific analysis.

Instead of previous ideas that can look for photo's ideology directly and literally, social semiotics focuses on the description of "semiotic resources" (JEWITT; OYAMA, 2001, p. 134). An important feature of the visual resources is the creation of potential meanings. Accordingly, resource description is not a description of one meaning; it is a description of the limited set of possible meanings that created by authors and viewers during their participation in the process of images interpretation ((JEWITT; OYAMA, 2001, p. 135).

Kress and Van Leeuwen made the breakthrough in the analysis of the images see e.g. (KRESS; LEEUWEN, 2006). Their works provide the researcher with the methodological tools which the investigator can use to define and explain the meaning in photos. Based on the idea of the linguist Michael Halliday, Kress and Van Leeuwen argue that the visual mode must perform certain visual and communicative metafunctions: ideational, interpersonal and textual (KRESS; LEEUWEN, 2006, p. 42-43). Using different visual elements, an author of an image affects how a viewer has 
to see a photograph or a picture. Ideational and interpersonal metafunction emphasise characteristics of the composition, while the textual metafunction gives the possibility to explore the overall composition of the image (KRESS; LEEUWEN, 2006, p. 40-42).

Kress and Van Leeuwen have noted (2006, p.14) that they seek the regularity of use of different visual elements in visual communication systems. The goals of their investigation do not involve revealing of the reasons of its use. Kress and Van Leeuwen believe that each image includes the expression of ideological positions, and cannot be considered as an objective image of reality (2006, p.14). This means that serious cross-cultural differences in interpretations are possible. "Meanings belong to culture, rather than to specific semiotic modes" (KRESS; LEEUWEN, 2006, p. 2). Here's how Kress and van Leeuwen further say on this:

[...] 'our' grammar is a quite general grammar of contemporary visual design in 'Western' cultures, an account of the explicit and implicit knowledge and practices around a resource, consisting of the elements and rules underlying a culture-specific form of visual communication (...) In the book we have, by and large, confined our examples to visual text-objects from 'Western' cultures (KRESS; LEEUWEN,, 2006, p.2-3)

The issue arises: can a multisemiotic theory help us to analyse Orthodox patriarchs photos, which are the product of Russian culture and Russian perceptions? The Indians, whom we will ask, are also representatives of non-Western cultures. However, after establishing the "West" orientation and the nonuniversality of their visual grammar, Kress and van Leeuwen suggested that 
in spite of the cultural specific, it can bring some benefit to nonWestern cultures:

[...] it is not a 'universal' grammar. Visual language is not - despite assumptions to the contrary transparent and universally understood; it is culturally specific. We hope our work will continue to provide some ideas and concepts for the study of visual communication in non-Western forms of visual communication (KRESS; LEEUWEN, 2006, p. 3).

In respect to ideology, it can be said that due to the difference of perception of photos in different cultures, they may produce a different ideology. If the authors/producers of Russian photos suggested one meaning, the result can be completely different in another culture and the photo will produce an unexpected ideology. Therefore, photos' ideology is not a constant. It provides the meaning potential where "the meaning potential is the range of significant variation that is at the disposal of the speaker" (HALLIDAY, 1971, p. 171).

Since our hypothesis assumes that Russians and Indians will perceive photos in different ways, the focus of our study will be on the interaction between a viewer, a producer and photos' represented participants that is the focus on interpersonal metafunction. Interpersonal metafunction was firstly described by M.A.K. Halliday in his works see Halliday and Hasan, 1985, Halliday 1978, 1985, 2003, 2014. He proposed that "[...] language is always also enacting: enacting our personal and social relationships with the other people around us" (HALLIDAY; MATTHIESSEN; HALLIDAY, 2014, p. 30). According to Halliday,

[...] we inform or question, give an order or make an offer, and express our appraisal of and attitude 
towards whoever we are addressing and what we are talking about. This kind of meaning is more active $[\ldots]$ this is 'language as action'. We call it the interpersonal metafunction, to suggest that it is both interactive and personal (HALLIDAY; MATTHIESSEN; HALLIDAY, 2014, p. 30).

In a case of an image, the interpersonal metafunction is shown through the relationship between the represented participant(s) and the viewer/reader. In addition, the relationship is established between the producer of the image and a viewer. In other words, a creator (an author) of an image may propose how the viewer should watch this image and its represented participant(s). Kress and Van Leeuwen named the creator and the viewer as "interactive participants". Interactive participants are "real people who produce and make sense of images in the context of social institutions which, to different degrees and in different ways, regulate what may be 'said' with images, and how it should be said, and how it should be interpreted" (KRESS; LEEUWEN, 2006, p. 114). At the same time, Producer and viewer know each other and are involved in face-to-face interaction, as when we make images of each other to keep in wallets or pin on pinboards $[\ldots]$ But in many cases there is no immediate and direct involvement. The producer is absent for the viewer, and the viewer is absent for the producer (KRESS; LEEUWEN, 2006, p. 114).

In result three kinds of relations between participants were established:

(1) relations between represented participants;

(2) relations between interactive and represented participants (the interactive participants' attitudes towards the represented participants); and (3) relations between interactive participants (the 
things interactive participants do to or for each other through images) (KRESS; LEEUWEN, 2006, p. 114).

These relationships can be studied with the help of relatively simple indicators, that are reflected in photos and created these interactive meanings. They are Contact, Social Distance and Attitude (see Fig. 1)

Figure 1 - Interactive meanings in images

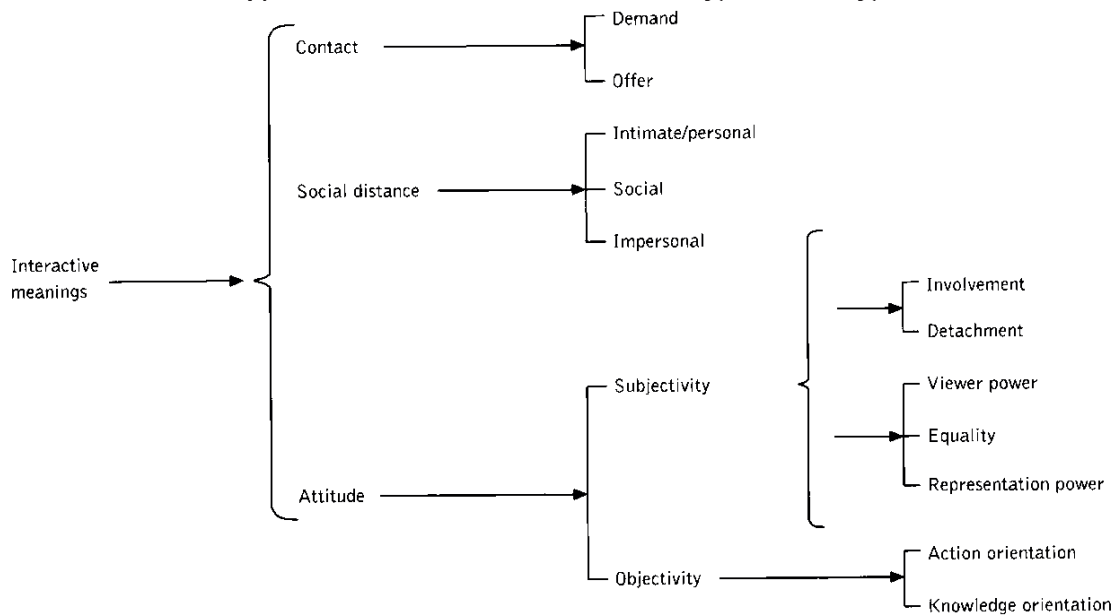

Font: Kress and Leeuwen, (2006, p. 149).

In our research we analysed two systems: system of contact and system of distance.

1) Contact. Use a "view" (gaze) promote establishing a relationship between the viewer and some person in the image. The concept of contact is particularly important for us because our each photograph or each picture book can contain the image of a person. In this context, the view is understood as a situation where the portrayed person looks directly at the viewer. Kress and 
Van Leeuwen (2006, p.122) argue that the depicted person directly addresses to the viewer and requires something from him/her. The specific character of established relationship between the depicted person and viewers depends on additional information obtained by other methods (e.g, facial expression or gestures). Also, the view, which is directed to something else in the image but not to the viewer, is significant. In this case, the viewer can observe the person as to whether he sees without any personal relationships or interactions with this person. Thus, the Contact can be encoded as Demand or Offer. For coders Demand can be indicated as "gaze at the viewer", Offer as "absence of gaze at the viewer" (KRESS; LEEUWEN, 2006, p. 148).

2) Distance. The physical distance between depicted people and the audience determines the social distance. In this sense, the physical distance is the size of the object in the image that creates the visual impression that he is at some distance from the viewer. Physical intimacy depicted with the audience, as well as between real people, represents some social proximity, the close relationship between them.

Photographs typically indicate location, since participants often are in specific locations (e.g. Patriarch in Church, meeting Patriarch and Pope in an airport). The visual representation of location distinguishes between foreground, that is, being more prominent or more salient, and background, being less prominent. To illustrate this, objects in location can have different shapes and sizes. Photographs usually demonstrate not only one or several objects but a situation of interaction between them. We can distinguish three distances: 
1. The close distance shows the situation and objects as if the viewer is engaged in it.

2. The middle distance - the situation and objects are shown full without much space around it.

3. The long distance - the situation and objects are shown for our contemplation only.

Kress and Leeuwen offered the following respective types of Distance: Intimate/personal, Social or Impersonal. Intimate/ personal Distance as "Close personal distance' is the distance at which 'one can hold or grasp the other person' and therefore also the distance between people who have an intimate relation with each other” (KRESS; LEEUWEN, 2006, p. 124). Social Distance as "Far personal distance' is [...] the distance at which 'subjects of personal interests and involvements are discussed"' (KRESS; LEEUWEN, 2006, p. 124). Impersonal Distance is 'Public distance' (KRESS; LEEUWEN, 2006, p. 125). In the process of coding of photos Distance can be encoded as Intimate/personal, Social or Impersonal. For coders Intimate/personal Distance can be indicated as "close shot", Social Distance as "medium shot", Impersonal as "long shot” (KRESS; LEEUWEN, 2006, p. 148).

\section{Status of Women in the Soviet Union}

Transformation of the new gender images and values is connected with changes of the status of women in the Soviet Union. One of the tasks of Soviet agitation system was the creation of women's inequality, despite the more than seventy years of 
propaganda. According to this propaganda, women's oppression was stopped after communist revolution. The position of women has changed in the condition of social life during late 1980s. The impact of economic and political reform was crucial for the transformation of gender images and stereotypes, especially change of women's image.

Woman's image as social active subject is developed by F. Engels, who developed the basics of socialistic theory in relation of women's emancipation. He suggested that if a woman could work outside home and housework and caring for children would be socialized, oppression will be stopped, and communist society will create real equality "between genders". The system of gender values based on gender equality, which had remained elusive ideal in all socialist countries. Not only Engels has overestimated the extent of which greater participation of women in the labor force will change the gender values, but Soviet Union as its satellite states in Eastern Europe has proved that it lacks the commitment which is needed to transform traditional gender images, stereotypes and values. The Soviet commitment to ideal of liberation of women ranged depending on the economic needs of state and national goals. Extensive research Lapidus (1978) found that the refusal of the Soviet experiment and establish egalitarianism and emancipation in gender relations were determined to three main factors:

1. ambiguous legacy of Marxism, which focused on a class relations, and does not focus on gender value orientation and gender relations;

2. the prevailing model of economic development of the country; 


\section{3. the Soviet model of political power.}

However, the policy in relation to women's mobilization and their involvement in the labor force was separated from the questions of transformation of gender images and stereotypes, directed on the female emancipation. Lenin recognized that many men with communistic views were suspicious to the agitation and propaganda among women, because they considered specific female work as unnecessary. In the end of the Second World War it became more evident that the Communistic party considered women as the bearers of potential economic and political resources, which are needed for the realization of government requirements. Women are suggested to work outside home and equality in public life was theoretically guaranteed for them. At the same time, the government started the campaign to strengthen the family as "fundamental social institution" ((LAPIDUS, 1978, p. 236). In fact, the government, on the one hand, formed the image of happy extended family in the public mind, and on the other hand, government has spread in the media, schools and institutes gender image of socialist superwoman. Such propaganda was aimed to justify the constant increase of female responsibilities in the workforce. This gender image is the image of the ideal woman, who works during the day time at the factory and educate children in the evening, and at the same time she can make the contribution in the goals of society through attending of Communist party's meetings and representing women's groups on these meetings. Thus, the formation of gender value orientations directed at the female emancipation, signifies the increase of woman's responsibility in all spheres of life.

Soviet women were not only active in home, which created 
barriers for vertical mobility, but they also suffered from different forms of discrimination from their colleagues and superiors. Such situation was related with dominant position of traditional patriarchal gender stereotypes and the image of women as dependent from men human. This was the major factor of the fact that society as a whole and especially in Communist Party didn't want to give power to women. Although Khrushchev mentioned that party was interested in fact that women can occupy more prominent positions, the real discussion about the transformation of gender images of women in Soviet society was not organized. During the Brezhnev period, this process continued because he had focused on ways to overcome this "double burden" of women and to find ways to decrease difficulties in everyday woman life. Brezhnev tried to improve social position of women by reducing the gap in salary between men and woman. (LAPIDUS, 1978, p. 228).

Saving of traditional gender images, values and stereotypes in the Soviet Union and the state's inability to include housework and childcare in the function of social institutions did not allow women to considerably improve their social status. The dominance of men in the social economic, political spheres was preserved. So, such a situation made difficulties to transform gender images in Soviet Russia. By the end of the 1980s, almost 80 percent of women in the Soviet Union were active participants of the workforce. This figure was higher than in any other country in Western Europe or North America, except of Sweden. However, despite the equal rights and the increase of the number of women with the higher education in scientific and technical fields, Soviet women were not more successful, than women in the West to achieve political power. 
It demonstrates the preservation of the traditional system of gender value orientations and images (RENDEL, 1981). Comparative study of socialist and non-socialist countries found that quantity of women in management positions in industry remained minimal. In the 1970 years approximately 4\% of working women in the United States were managers, officials or owners. In the UK, the number of managers among women did not exceed $1 \%$ of all managers in the country. However, in the Soviet Union, as well as in all socialist countries, women were less successful in achieving of leading position in the economy. Although they were more than $50 \%$ of the workforce, only $0.5 \%$ of managers and directors were women (WOLCHIK, 1981). This determines the formation of gender images of women as working on low-income positions and occupies the low social status in society.

The Soviet Union consistently argued that the formation of the new gender image of working woman was the part of plan of total reconstruction of society. But the reality was surprisingly different from the planned objectives. This gender image saved in the political sphere because the representation of women in the political structures of the Soviet Union is often overestimated. A relatively high percentage of women in parliament from 1950 should not be considered as the indicator of real political power. Although parliament included about $30 \%$ of women during the 1980s, woman rarely occupied leadership positions as managers in the country. Man had leadership and real political power in the Soviet Union. Men were the real source of political power, which created conditions for saving of patriarchal gender image of a man as the head of family and government. Approximately $70 \%$ members 
of parliament during the 1980's were men, who occupied leadership positions in the Communist Party, as opposed to women. In 1986there was $4 \%$ of women in the Central Committee. This number was similar to the number of women having the authority to make political decisions in United States and United Kingdom (BROWNING, 1987, p. 21). However, these women often got the place in the Central Committee, simply because they presented the "communist ideal" image of woman and not because of their political experience.

The growth of Gorbachev's power impacted different aspects of Soviet society, and began a new era for the formation of contemporary gender images of women. Re-structuration of the economy and the need of cuts of the labor force, and the rise of social conservatism challenged "dual function" women as mothers and workers. Political reforms have confirmed the existence of these problems.

Transformation of gender images and values intensified when in the year of 1985, Mikhail Gorbachev claimed the economic policy of reform which is directed on the change of socialist economic system. Rebuilding or reconstruction was caused by the change of Soviet leader's consciousness. Soviet government decided by such way to overcome the economic crisis. This change of consciousness is related with the problem of transition to the new system of gender value orientations based on the women's emancipation. So, women enthusiastically accepted Gorbachev's idea about the changes and formation of new gender thinking. The openness and democratization gave women, important support and gave the feeling of hope. For the first time since 1930, such topics 
as the use of contraception and prostitution, rape were discussed in the public debate. The new environment gave possibility for the objective study of the transformation of gender images of women and development of groups of independent women. Thus, the emergence of political and social transformations in the Soviet Union in the 1980s inspired a nationwide program for the further advancement of women. However, women were quickly disappointed because of the reform's results.

Economic changes imperceptibly became the full-scale restructuration of the system. At this case there was no concept of the final result. In 1985, the Soviet gross national product (GNP) grew by less than 1\%, and although GNP has increased on 4.1 percent in 1986. In the start of 1990, GNP became negative. By the end of 1990, it decreased by 3.7 percent (KOTZ, 1992). Decreasing of economic growth is more intensified, which impacted on the social situation of bearers of the male and female genders. Such phenomena, as women's daily duties, food shortages and rising of prices did not give the women, time to enjoy newly appeared freedoms, influenced by the formation of the new gender images independent women. Gorbachev period "identified, condemned and mourned..., but it was not betrayed". (BUCKLEY, 1992, p. 7).

The impact of gender values orientation of women became weaker by reason of economic deterioration and of social problems. The men-politicians have found a simple solution of these social problems: to reduce the labor force. They began to return to traditional gender image of women as a housewife who doesn't work. So, as they thought, women would valance their jobs and return to execute home tasks and child care. Gorbachev's government has not 
justified its unwillingness to protect women from the dominance of conservatism and to defend women's rights. Gorbachev (1988), in his book "Perestroika and new thinking for our country and for all world" proposed the way to solve the social problems arising from the women's emancipation: free them from jobs and return them into the house with their children (GORBACHEV, 1988, p.56). New gender images of women as housewives and homemakers were generated. Women should return to their "feminine" mission.

\section{Transformation of Gender Images and Values in Modern Russia}

However, since 1991, year gender images, stereotypes and values had been dramatically changed under the influence of radical political and economic transformation. The August coup 1991 year in the Soviet Union forced President Gorbachev to give up power. This event led to the disintegration of Soviet Union and the emergence of the first Russian state. Immediately after Yeltsin became President, he along with his group of advisers insisted on Russia's transition to open and free market economy. Initially constrained by the political opposition, the newly elected president presented the program included four interrelated principles:

(I) macrostabilization of financial and fiscal conditions of control of inflation;

(II) liberalization of prices;

(III) the privatization of state organizations;

(IV) reform of country's legal system, political authorities and banking system. 
These social, political and economic reforms have significantly influenced the gender stereotypes and values of the Russian women. Three of the most serious problems faced by young women:

1. unemployment,

2. the reduction of social assistance and government support

3. the revival of social conservatism, seeking to recreate full Russian Patriarchate and patriarchal system of gender images and values.

Such tendency as the increasing of services sector, may have been useful for the formation of Western, liberal and feminist system of gender images and values. This is connected with the fact that women in these "non-productive" sectors were in a larger proportion. Increasing the number of women in leading industries, women engaged in business and women occupying their high positions in the socio-economic hierarchy leads to the formation of the image of independent business woman. The Russian legal system of the 1990's did not make obstacles for women to start their own business. However, women were more afraid to get involved in business which was illegal during Soviet era. In addition, women tend to have less business social ties and more limited access to working capital to start business than men.

At the beginning of the 1990's, St. Petersburg sociologists have conducted investigations, which showed that bearers of feminine gender were more pessimistic and scared of risks of economy's marketization. The study of 4500 people who were aged 20-50 years, showed that $11-20 \%$ women believed that the transition 
to market economy was unacceptable. At the same time, only $4-6 \%$ of men in the same age shared such opinion (LEHMANN, 1991). As expected, women (and men), who have the more age, less level of education and worked in the government sector considered transition to a market economy as unsatisfactory. We can assume that there is a direct correlation between gender images and values of women (and men) and their socio-economic status and education. The higher socio-economic status and education level, the more the processes of transformation of gender values intensified in the minds of women or men. At the same time, activity of women's organizations (in addition to economic and political factors) played their significant role in the transformation process.

During the 1990s, social understanding of gender problems increased. In the same period, those institutions who presents Russian women has not changed after the collapse of Soviet Union, but they received help from a lot of international women's organization abroad. During 1990s, activity of 300 women's organizations all over Russia was not limited by Moscow and St. Petersburg. In small towns around Moscow, Siberia and Volga region, gender stereotypes and images were changed with support of various non-government organizations. As a result, behavior of some part of women in Russian has changed. Women have started to take part in market economy and political liberalization.

We can identify four types of Russian women's organizations:

1. conservative type;

2. the independent women's organizations;

3. organization of professional self-help; 


\section{4. feminist organization.}

Independent and conservative groups and organizations have the greatest potential of impact on the transformation of gender images and values, and in general on increasing of quantity of women in government and public organizations. Moscow Center for Gender Studies (Russian Academy of Sciences) in leader among the independent women's groups.

\section{Theoretical Background}

\section{Methodology}

Transformation processes of gender images emerged especially brightly in modern Russian advertising and social media, which has become the object of study of Russian and Western sociologists, culture experts and advertising specialists (GROSHEV, 1999 , p. 2-3). Russian scientists focus on the modern gender image of women in advertising. (AL'CHUK, 1998; GROSHEV, 1999; VORONINA, 2000). The presentation of the male body in the information space has dramatically changed. The man should pay the same attention as women to his clothes and his body image, which requires a serious investment of time and financial resources (PETROV, 2010, p. 403). The body is transforming more and more in "idol" for man and women. Standards of mass culture impose "ideal" images of men and women formed in the western culture. Modern young men as well as women, are engaged in the conscious construction of its bodies. This liberalization in the sphere of images of male body expressed in changing of the rules of his image. In particular, as I.S. Cohn noted that in erotic magazines, 
in advertisements, in the classical paintings of the past, the male body is usually depicted smooth and hairless (VORONINA, 2000). Now preferences of men and women has changed. for whom it seemed the biggest attraction was the man's body with the hair, which was manifested in the formation of the corresponding gender of advertising images (PETROV, 2010, p. 403).

The research of Dudareva (2003, p. 121), Groshev (1999) and Petrov (2010, p. 403) identified the following types of gender images of men in the modern Russian advertising XXI century.

1. The "ideal" man. He has slim appearance, moderate unshaven, with moderate hair on his chest.

2. Men who are overweight. As he presented in advertising he doesn't have high and even middle intellectual abilities.

3. Thin man. He also does not have the high and average intellectual abilities and he is coward.

4. Professional. This is a man who has specific knowledge in any field and knows how to apply them professionally. For example, teacher.

Creators of the advertising product prefer to depict "ideal" man and doesn't want to depict 2 and 3 types. Based on the ideas A. Dudareva, I. Groshev and M. Petrov we conducted research of gender images of women in the modern Russian advertising.

\section{Data}

The data comes from 300 images of the Russian women in advertising. 300 images were specifically chosen by the author in order to be acceptable for coding. The study was conducted in two 
stages. In the first stage, author encoded the full photograph corpus according to interpersonal metafunction's codes based on the Kress and Leeuwen's Systemic Functional Linguistics for images (the system of contact: demand, offer) and chose 12 advertising images.

Then we created the formalised interview guide. Each system ("Contact", "Distance", "Attitudes") has two kind of questions: a question with a name of code and a question with the description of code. The formalised interview guide was trialled by three independent respondents. Upon their recommendations, we made minor changes to the phrasing of some response options and excluded a choice: "It is hard to say ", therefore then it would be the main choice as our preliminary testing of the formalised interview's questionnaire has showed.

We have found Russian and Indian women-respondents. The sampling method is snowball technique (GOODMAN, 1961). We interviewed 12 Russian and 12 Indian women because only such quantity of the women could be found in a given time period in St. Petersburg. We showed to respondents the selected images and asked to do encoding of images of advertising. We will present the result of two important system of interpersonal metafunction: system of contact and system of distance.

\section{Results}

Results of coding of Contact are presented in Table 1. Despite the fact that according to both Indian and Russian coders the choice of Demand prevails than the choice of Offer in the full photos'corpus, there are differences between Russians and Indians (see Table 1). 
Table 1 - Results of coding of Contact

\begin{tabular}{|c|c|c|}
\hline & \multicolumn{1}{|c|}{ Indians } & Russians \\
\hline Demand & 81,6 & 66,5 \\
\hline Offer & 18,4 & 33,5 \\
\hline
\end{tabular}

Font: Author.

As we can see in Table 1 quantity of images being encoded by Indians as Demand is ranged from $81.2 \%$ to $81.6 \%$. At the same time coding Demand by Russian is in diapason from $64,1 \%$ to $66,5 \%$. During analyses these differences, we found examples showing the full consent and the full absence of agreement in the encoding. For instance, Figure 1 "Good holiday for people who work hard" is example of full agreement in the coding of Contact between Russians and Indians coders. Perhaps it is caused by the fact there are no any doubts that "gaze at the viewer" is absent (see. Fig 1, 2). 
Figure 2 - Soviet Union's advertisement of holidays

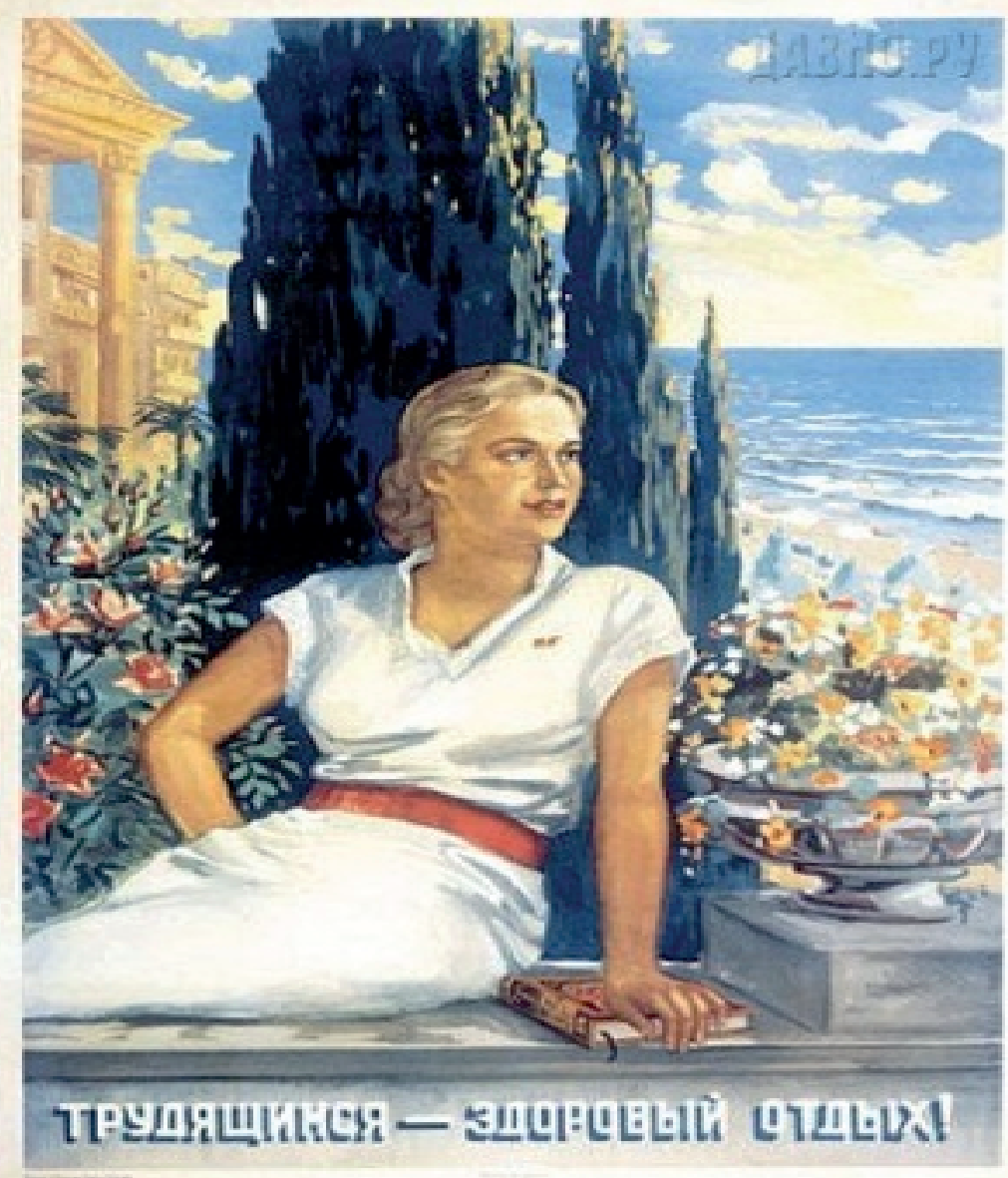

Note: Both Russians and Indians encoded this photograph as Offer.

Font: Nesterova-Berzina (2015) 
254 The transformation of gender visualization in photography: Soviet and Russian multisemiotics

Figure 3 - Car's Advertisement in modern women magazine.

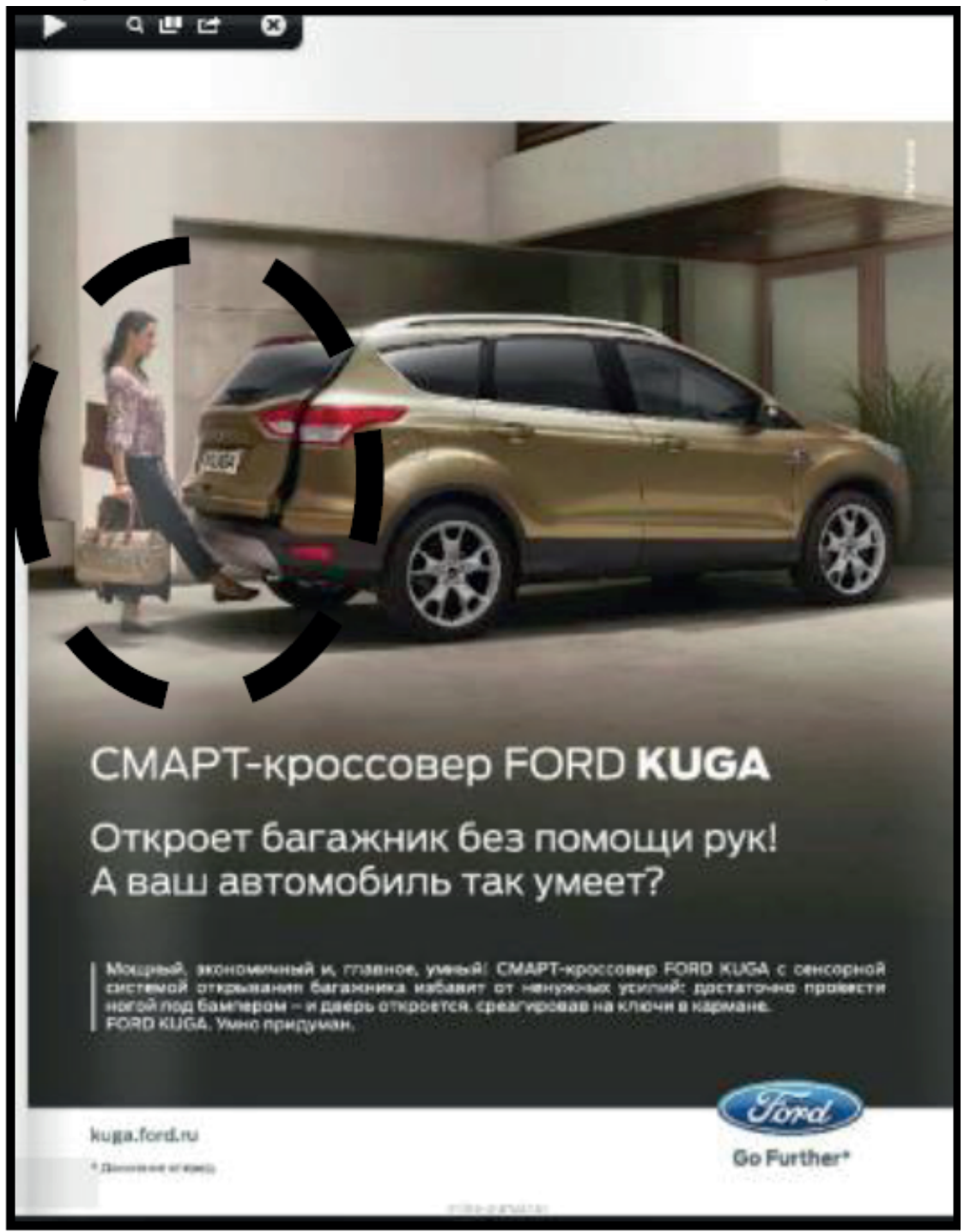

Note: Both Russians and Indians encoded this photograph as Offer

Font: Chevrolet... (2015)

"Distance "according to Kress and Leeuwen can be encoded as Intimate/personal, Social or Impersonal. For coders 
Intimate/personal Distance can be indicated as "close shot", "Social Distance as" "medium shot ", Impersonal as "long shot" (KRESS; LEEUWEN, 2006, p. 148). Below we presented results of coding "distance" "by two Russians and two Indians coders.

Results of the coding of Distance are presented in Table 9 and Figure 7. As we can see, there is some tendency for Indians to perceive more photos as Intimate/personal, while Russians can see more cases of Impersonal distance (see Table 9). In regard to the coding of Impersonal, this difference reached 13,1\% for Indians and $22,2 \% \%$ for Russians. Difference in Intimate/personal coding is less; it vary from $12.2 \%$ for Indians to $9,7 \%$ for Russians. These differences can be found because of the size of the images' corpus. At the same time, both groups encode most part of the photos as Social distance (from $68.1 \%$ for Russians to $74,7 \%$ for Indians).

Table 2 - Results of coding of the system of Distance (\%).

\begin{tabular}{|c|c|c|}
\hline & \multicolumn{1}{c|}{ Indians } & 9,7 \\
\hline Intimate/personal & 12,2 & 68,1 \\
\hline Social & 74,7 & 22,2 \\
\hline Impersonal & 13,1 & 100 \\
\hline Total & 100 & \\
\hline
\end{tabular}

Font: Author.

Thus, Russians' coding of Distance differs slightly from Indians' coding. We have chosen the photos with the full consent and full divergence in coding to illustrate these differences. In spite 
of the fact that the physical distance in some images looks various, Indians and Russians encoded it similar.

In the second stage, women evaluated types of participants and answered to the open questions. The most important question was related with the type of gender images. The main result of the study is typology of gender images (see table 3 ) of woman in modern Russian advertisement.

Table 3 - Typology of gender images of woman in USSR and modern Russian advertisement

\begin{tabular}{|c|c|c|c|}
\hline & & Indians & Russians \\
\hline \multirow{2}{*}{ The object of sexual passion } & USSR & 0 & 0 \\
\hline & Russia & 66,6 & 58,3 \\
\hline \multirow{2}{*}{ Model } & USSR & 16,6 & 16,6 \\
\hline & Russia & 25 & 25 \\
\hline \multirow{2}{*}{ Homemaker } & USSR & 50 & 58,3 \\
\hline & Russia & 16,6 & 16,6 \\
\hline \multirow{2}{*}{ Simpleton } & USSR & 0 & 0 \\
\hline & Russia & 8,3 & 8,3 \\
\hline \multirow{2}{*}{ Close friend } & USSR & 8,3 & 8,3 \\
\hline & Russia & 7,6 & 8,9 \\
\hline \multirow{2}{*}{ Business woman } & USSR & 0 & 0 \\
\hline & Russia & 58,3 & 75 \\
\hline
\end{tabular}

Font: Author. 
1. The object of sexual passion. It is important to emphasize that in this image the soul, moral and intellectual qualities of girl or woman does not matter. Only value of her body has significance. Such image of body is some kind of bonus to the product, which it is needed to buy by man. We fully with I. Groshev that this image of woman is the most popular. "Pornographic female body used in advertising doesn't know limits [...] Advertising-pornographic genre with the help of the female body is the most [...] "apocalyptic" "from all" "carnal discourses" (GROSHEV, 1999, p. 3). $66,6 \%$ of Russians and $58,3 \%$ Indians think that this image is prevailed in modern Russia's advertisement and nobody will agreed that object of sexual passion characterized USSR's advertisement.

2. The image of the model. The use of this image is a factor in increasing the prestige, the solidity of the company or increasing reputation. Model Girl can be used for advertising various goods on the principle of similarity. Using of such image of woman also increased in modern Russia's advertisement in comparison with USSR's advertisement.

3. The image of the homemaker. The homemaker is a woman who is engaged in housekeeping and childrearing. Such stereotypical image characterize USSR's advertisement: $50 \%$ of Indians and 58,3\% of Russian think that image of housekeeper prevailed in USSR. Only 16,6 respondent suggest that image of housekeeper 
prevailed in modern Russia advertising.

4. The image of the "simpleton". It is the middle-aged women 's, who believe advices of friends or television characters and becomes the fan of the goods.

5. Image close friend. A woman who has the fullness of information about the advertised product and talks about it with those who ask or doesn't ask. As we can see in the table Such image isn't popular in Russia advertisement.

6. The image of a business woman. Business woman expresses such qualities as self-confidence, independence, control of the situation. In advertising such type of woman is mainly displayed in the business suit, with a determined look. Age does not play a significant role in the characterization of destination. This can be a young girl or older woman, who has especially her strong-willed qualities ... A woman at the computer is the most common form of the image of a working woman. (ORLOV, 2013, p. 57) 58,3\% of Indians and $75 \%$ of Russian think that image of business woman prevails in modern Russia advertising. In USSR business was forbidden, so such it was impossible to promote such image.

\section{Discussion}

Culture and ideology have an influence on photograph's perception and its perception is very important to images' producers. The role of gender images in cultural/ideological/political affairs will 
likely grow as internet, $\mathrm{TV}, 3 \mathrm{D}$, virtual reality continues to increase in importance. Despite some competition with video streaming, photographs still play a foundational role in any communication process and we still know a little about viewer's perception. Our research tries to expand the understanding of images' role by focusing on the area how interactive meaning of images is created and a received by audiences from non-Western cultures.

Our study points out the importance of the Kress and van Leeuwen "visual grammar" in studying of interactive meanings in photographs. In our view, the social semiotics' approach to the analysis of different forms of cultural communication allows us to explore less known aspects of the very influential cultural/ ideological institutions which "symbolic" power depended on the use of visuals.

Similarities in the Russian and Indian perceptions of the 'gender images' connected with geometrical proportions. Russian and Indian perceptions of geometrical angles and distance almost similar. It is very important because open possibilities for further research based on the Kress and van Leeuwen theory. During our research, all problems with interpretation of angles and distance were concerned with ideological/cultural reasons and requests, and in fact were the results of interpretations. However, ideological/ cultural reasons exist, and their influence is rather strong. These reasons are going through all stages of our research. The first challenge was concerned with the names of contact's codes that are "demand" and "offer".

In spite of the fact that both Russia and India are nonWestern countries, it is impossible to think that they are the same. 
From this point of view, the term "non-Western" is the name of something unknown, rather hidden from the Western analytical eyes, the demarcation of white spot on the map of consciousness, than it is the explanation of something that is really "non-Western". For example, our Russian and Indian coders and respondents demonstrate very different strategy in coding/evaluating of "demand" and "offer". It was a surprise for us, that Indians showed understanding of "demand" with some similarity with "Western" as it was described in the Kress and Leeuwen, and Lapidus, theory. It seems Indian "demand" should look like it is in Figure 4. At the same time, Russians faced with the problem that "demand" couldn't be clear described geometrically. "Demand" and "offer" for Russians are different types of behavior when "demand "is a strong request while "offer" is a soft request. So, there are no reasons for Russians to think that Figure 4 demonstrates a strong request and Russians can evaluate it as "offer". "For instance, in order to be "demand" this Indian gaze should be gloomier, maybe even spiteful (see Figure 4). However, it is not a problem for Russians to see "demand" at any angle, including in a profile (see Figure 5).

Figure 4 - An example of the Indian "demand "(the choice of one of the Indian coders rom open internet sources)

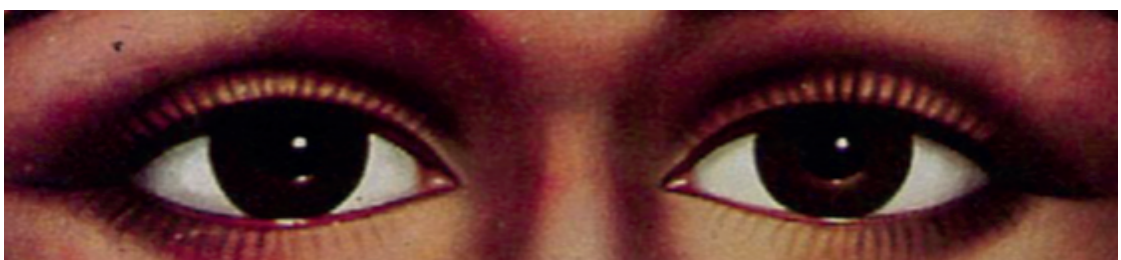


Figure 5 - An example of the Russian "demand "(the choice of one of the Russian coders from website kremlin.ru)

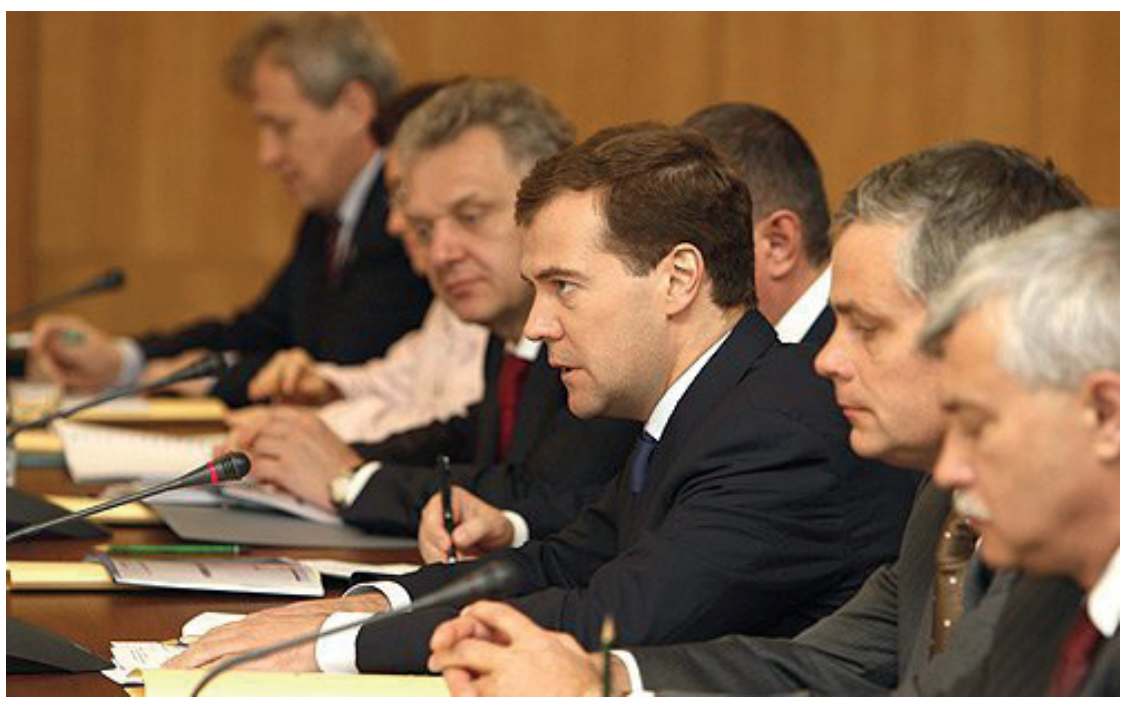

In our examples, we can see these problems of the linguistic description of visual phenomena. We cannot describe/compare the photos of different cultures without words, at the same time words and their translating in different languages can lead to the "wrong"/peripheral/unusual way of thinking about images. In our research, we give the interpretation of these problems as culturally determined. So, we believe that words make ideology transparent as it happens in our examples with Russian following to own culture and Indian attempts to reconfigure this culture according to Indian traditions. The line undressed between Russians and Indians passed through all codes. There was no one code in which Russians and Indians would not formulate different opinions about gender images of woman. 


\section{Conclusions}

Result has shown that "offer" can be seen as more pleasurable characteristics of system of behavior in advertising It may cause superposition of encoding tasks and ideological goal. In this situation error or unwillingness to make encoding according to instruction can happen. All coders read our instructions with codes in Russian, which was printed. They kept this table in hands during consideration of images. There wasn't translation into Russian, because we asked students before and they replied that they had known English. However, when respondents were answering to control question part of them gave different answers to main and control question.

1. According to the result of interview with coders, establishment of the position of the viewer give the most of information about the participant. According to Russian women the level of the symbolic power of the viewer is set by the vertical perspective. This level interacts with the level of involvement to determine the significance of behaviour.

2. Russian women have a neutral attitude towards the encoding and words. It is possible that it is not caused by difference of cultures, but the reason is rooted in the level of knowledge and involvement in Russian tradition of gender representation.

3. Russian has more higher tendency to choose offer, and Indians has more higher tendency to choose demand..

4. Russians evaluate the distance as more impersonal. 
Indians evaluate the distance as more social.

Thus, as shown by the analysis of the gender images, value orientations were transformed within modern Russian society under the influence of economic, political and socio-cultural factors. The gender of a woman, her body and figures as demonstrated in the media, very often was object of sexual exploitation, when the impact of using the image and play with human sexual passion forces someone to commit certain actions, such as buying goods. This characteristic of our commercialization of gender images makes a person, both men and women, into a commodity. Gender is transforming into the object that can be purchased and can be enjoyed. In this moral and spiritual value orientations, there is no impact on contemporary dominant social system of gender images.

\section{References}

AL'CHUK, Anna. Metamorfozy obraza zhenshchiny v russkoy reklam, Tendernyye issledovaniya. Khar'kov: KHTSGI, 1998. Vyp. 1.

BARTHES, Roland. Camera lucida: reflections on photography. New-York: Hill and Wang, 1981.

BRECKNER, Roswitha. Bildwelten: Soziale Welten. Zur Interpretation von Bildern und Fotografien. Vienna: Institut für Soziologie, Universität Wien. Online-publikation 'Visuelle Soziologie'. 2008. Available in: <http://www.univie.ac.at/ visuellesoziologie/Publikation2008/VisSozBreckner.pdf $>$. Access in: 1 Aug. 2016.

BROWNING, Genia K. Women and politics in the USSR: consciousness raising and Soviet women's groups. New York: St. 
Martin's Press, 1987.

BUCKLEY, Mary. Perestroika and Soviet women. Cambridge: Cambridge University Press, 1992.

CHEVROLET Sequel. Wikipédia: a enciclopédia livre. Available in: <https://pt.wikipedia.org/wiki/Chevrolet_Sequel>. Access in: Oct. 2015

DUDAREVA, A. Reklamnyy obraz. Muzhchina i zhenshchina. Moscow, 2003.

GOODMAN, Leo A. Snowball sampling. The Annals of Mathematical Statistics, Ithaca, v. 32, n. 1, p. 148-170, 1961.

GORBACHEV, Mikhail S. Perestroyka i novoye myshleniye dlya nashey strany i dlya vsego mira. Moskow: Politizdat 1988.

GROSHEV, I. V. Obraz zhenschiny v reklame, Zhenshchina. Gender. Kul'tura, Pod red. Z. A. Khotkinoy. NL Pushkarevoy. NI Moscow: Trofimovoy, 1999. S. 57.

HALLIDAY, Michael Alexander Kirkwood. Language in a social perspective. Educational Review, Abingdon, v. 23, n. 3, p. 165188, 1971.

HALLIDAY, Michael Alexander Kirkwood; MATTHIESSEN, Christian; HALLIDAY, Michael. An introduction to functional grammar. London: Routledge, 2014.

JEWITT, Carey; OYAMA, Rumiko. Visual meaning: a social semiotic approach. In: LEEUWEN, Theo van; JEWITT, Carey (Ed.). Handbook of visual analysis. London: Sage, 2001. p. 134156.

KOTZ, David. The direction of Soviet economic reform: from socialist reform to capitalist transition. Monthly Review, Ithaca, 
v. 44, n. 4, p. 14-34, 1992.

KRESS, Gunther; LEEUWEN, Theo van. Reading images: the grammar of visual design. 2. ed. London: Routledge, 2006.

LAPIDUS, Gail Warshofsky. Women in soviet society: equality, development, and social change. Berkeley: University of California Press, 1978.

LEHMANN, Jennifer M. The question of caste in modern society: Durkheim's contradictory theories of race, class and sex. American Sociological Review, Notre Dame, v. 60, n. 4, p. 566585, 1991 .

MARTÍNEZ LIROLA, María. A systemic functional analysis of two multimodal covers. Revista Alicantina de Estudios Ingleses, Alicante, n. 19, p. 249-260, nov. 2006.

NESTEROVA-BERZINA, Maria Alexandrovna. Healthy vacation - for the workers! Available in: <https:/www.allposters.com.au/sp/Healthy-Vacation-for-the-Workers-posters_i13406827_htm>. Access in: Oct. 2015

OREH, E. A. The photo of the head of the state as a tool to create an image of the soviet reality. [Russian]: Vestnik SanktPeterburgskogo Universiteta, 2012. Serija 12, Sociologija, 1. p. 192-200.

ORLOV, A. Female images in male contexts advertising. Modern Discourse Analysis, n. 9, 2013.

PAVENKOV, Oleg; RUBTCOVA, Marii. Coping behavior of orthodox religious students in Russia. Journal for the Study of Religions and Ideologies, v. 15, n. 44, p. 205-224, $2016 \mathrm{a}$.

PAVENKOV, Oleg; RUBTCOVA, Mariia. Love as a concept 
in the religious philosophy of Pavel Florensky. Anales del Seminario de Historia de la Filosofia, Saint Petersburg, v. 33, n. 1, p. 163-180, 2016 b.

PETROV, M. S. Gendernyye obrazy i stereotipy sovremennoy rossiyskoy reklamy. Izvestiya Rossiyskogo gosudarstvennogo pedagogicheskogo universiteta im. A.I. Gertsena, n. 124, S. 404405, 2010.

RENDEL, Margherita. Women, power and political systems. London: Croom \& Helm, 1981.

SCHILL, Dan. The visual image and the political image: a review of visual communication research in the field of political communication. Review of Communication, Tempe, AZ, v. 12, n. 2, p. 118-142, 2012.

SHMELEV, Ilya. Beyond the drama triangle: the overcoming self. Psychology: Journal of the Higher School of Economic, Moscow, v. 12, n. 2, p. 133-149, 2015.

TAGG, John. The disciplinary frame: photographic truths and the capture of meaning. Minnesota: University of Minnesota Press, 2009.

VENTSEL, Andreas. Visualization of "people" in Soviet Estonian public photographs of the Stalinist era. Social Semiotics, Tartu, v. 20, n. 5, p. 593-612, 2010.

VORONINA, Olga. Problemy erotiki i pornografii v SMI. In: AL'CHUK, A. Zhenshchina i vizual'nyye znaki: sbornik statey: pod red. Moscou: Ideya-Press, 2000. p. 87-106.

WOLCHIK, Sharon L. Elite strategy toward women in Czechoslovakia: liberation or mobilization? Studies in Comparative Communism, New York, v. 14, n. 2-3, p. 123-143, 1981. 